Article

\title{
The Effects of Material's Transport on Various Steps of Production System on Energetic Efficiency of Biodiesel Production
}

\author{
Olga Orynycz ${ }^{1, *}$ and Antoni Świć ${ }^{2}$ \\ 1 Department of Production Management, Bialystok University of Technology, 15-351 Bialystok, Poland \\ 2 Faculty of Mechanical Engineering, Institute of Technological Information Systems, \\ Lublin University of Technology, 20-618 Lublin, Poland; a.swic@pollub.pl \\ * Correspondence: o.orynycz@pb.edu.pl; Tel.: +48-746-98-40
}

Received: 28 June 2018; Accepted: 2 August 2018; Published: 3 August 2018

\begin{abstract}
Rapeseed plantation biodiesel production systems require the transportation of goods, like raw materials, machines and tools, and products between various conversion stages of agricultural as well as industrial subsystems. Each transportation step requires the consumption of some energy. This consumption decreases the net amount of energy delivered out of the biofuel production system, and consequently decreases the energetic efficiency of the system. The majority of studies on biofuel sustainability are done by means of the LCA method with the use of a data average for some region and period of time. Such analyses do not reveal the possible causes of the conclusions determined. The present work deals with computer modelling of the influence of the energy consumed on those transport routes on the energetic efficiency of the production system. The model enables determination of the effects caused by changes introduced to technological parameters. The effects caused by variation of fuel consumption, the load capacity of transportation means, size of plantation, distribution and sizes of individual fields, distances between fields, plantation yield, and finally the distance between the plantation and the industrial facility are studied using the numerical model developed earlier. This approach is aimed towards identifying the reasons for the behavior of a system controlled by many somewhat coupled variables.
\end{abstract}

Keywords: biodiesel; energetic efficiency; modelling; transport; sustainability

\section{Introduction}

The pollution of the environment, the exhaustion of natural supplies and the growth of wastes disturb the equilibrium of the natural environment. Growing violation of this equilibrium presents problems to the present world. The majority of areas feel dangerous threats as being the consequences of pollution of waters, soil and air, which may lead to the contamination of products.

The main foundations of the notion of sustainable development were formulated in the report "Our Common Future" in 1987 [1]. Sustainable development is a widely applied notion, but is interpreted in various ways. In the majority of cases, the definitions relate to the equilibrium of the environment, the economy and society. This is the strategy of the endeavor for stately life within the limits determined by that what is biologically and physically possible with the assurance of natural equilibrium and the durability of processes [2,3].

Various definitions and various interpretations of sustainable development existing in the literature frequently emphasize its multidimensional character [4].

The development of technology, from one side, contributes to the reduction of human's dependence on the nature, but on the other side, leads to an even stronger response from the 
environment. Dynamism of technological progress results in unbalanced economic growth, and leads to the disproportion of development on the local as well as on the global scale. The development of production should keep up not only with demographic growth, but also so the natural environment has to be taken into account. The durability of development has the essential meaning for sustainable development.

During the years 1950-1960 it was also recognized that environmental problems may also result from food economy and agriculture [5].

Consequently, for the dissemination of sustainable development on the global scale [6] the possibility of the implementation of this conception also in agriculture should be determined. Sustainable development joins the conception of multi-functionality, the creation of conditions for the various forms of economic activity; and respect for environmental, cultural and social values in country areas.

Small elementary efficiencies are some of the essential barriers for the implementation of this strategy in the agro-technical system. Effective work towards harmonious, sustainable husbanding of resources must, however, be supported by the sustainable development of energy production $[7,8]$, which should be taken into account in biofuels production.

The need for the adaptation of technology to the requirements of sustainable development determines the directions of scientific research in the range of agriculture. It also indicates that renewable energy may happen to be the effective way to achieving sustainable development [9]. Recently, computer modeling studies have also suggested [10] a positive role of biofuel production towards the sustainability of agriculture.

The productive activity in agriculture may cause pollution of the air. Particularly large agricultural farms might show strong influence in this respect. The efficient forwarding system is one of the factors assuring the development of the modern economy, and as such, it should be taken under consideration when efficiency in the agro-technical system is considered. Because the demand on transportation, both in agricultural as well as in industrial systems, continuously increases, the suitable selection of transportation means for transport materials and loads seems to play an important role.

The agricultural works consist of numerous agro-technical operations, dependent on the seasons of the year, and requiring the appropriate choice of machines and devices as well as the means of transportation. The character of works and the continuous improvement of agricultural technologies also affects the choice of the methods of tillage.

Energetic efficiency of biofuel production is understood as the ratio of the amount of energy available from the production system to the amount of energy needed to maintain the working system. This definition, however, is often used in an ambiguous way [11,12]. Doubts are related to the choice of data taken into account in calculations as well as to some aspects of boundary conditions, and to the possibility of including factors previously omitted.

Energetic efficiency of agricultural production, and especially biofuel production, is an object of numerous studies e.g., Fontaras et al., [13], Russo et al. [14], Talens et al. [15], Liao et al. [16], Nasir et al. [17], Okoro et al. [18], Giraldi-Díaz et al. [19], Bacenetti et al. [20]. The work in Reference [13] gives an integrated assessment of products leading to the production of biofuels, and indicates the possible role of using waste biomass as a resource for biofuel production, while [14] considering the consequences of biofuel production in supporting rural economy. The work in Reference [15], in turn, points out the low exergy loss in the biodiesel production that indicates the high level of energy availability conserved in their biofel production. Because of that reason, Reference [17] indicates good level of sustainability reached in biodiesel production. The papers [21-24] deal with formal and legal aspects of the contractors bidding process and analyze possible competitiveness, as well as indicate the role of transport in urban life organization. The work in Reference [23] gives an analysis of drivers for technology development, which is also important for biofuel's production, and achieving more sustainable processes with higher energetic efficiency. The majority of studies on biofuel's production have been performed with the use of LCA (life cycle assessment) procedures. These procedures, 
since they are strictly normalized, are convenient for the evaluation of the given situation, but do not allow the use of process parameters as variables in order to study their effects on the final efficiency of a system. The procedure proposed in References [25,26] enables such an approach to the studies of energetic efficiency of biofuel production systems.

The present work is the "case study", in which real data, received from various producers, are used to be compared with purely "virtual" model computations.

The aim of the present work is to evaluate the influence of several agro-technical operations, and of internal transport, i.e., the transport of goods and machinery between the fields before and after agricultural operations, on the energetic efficiency of the agricultural production subsystem. This evaluation is made in relation to tillage technology, and should enable conclusions towards the sustainability of agriculture.

\section{Methods}

The main methodology of this work is the computer modelling based on both real data from rapeseed production plants, and computations that take into account elementary operations performed in agricultural practice. The later approach enables the computation of dependencies based upon derived functions, and assumed ranges of values of variables.

The new approach to the computer modelling of energetic efficiency of the biofuel production system was recently proposed [25]. The approach contains a possibility of "ab initio" computation from elementary assumptions or with the use of empirical data. The energetic efficiency of the plantation can be expressed as the ratio $P_{r e n} / P_{i n}$, where $P_{r e n}$ is the energy obtained in the form of biofuel at the end of the production system, and $P_{i n}$ is the total energy needed to be supplied in order to enable all the necessary transitions occurring in that system. When $P_{\text {in }}$ is composed of many contributing fluxes of energy, $P_{i n, i}$ it is convenient to define partial energetic effectiveness, $\varepsilon_{i}$, for individual parts of the system structure.

In such a case [14]:

$$
\varepsilon_{i}=\frac{P_{r e n}}{\sum_{i} P_{i n, i}}
$$

and the total energetic efficiency of the system can be written as:

$$
\varepsilon=\left(\sum_{i} 1 / \varepsilon_{i}\right)^{-1}
$$

In the modelling computations considering the situation when only one fuel is produced in the system, $P_{\text {ren }}$ can be expressed as:

$$
P_{\text {ren }}=S \times M \times \Omega \times V_{\text {ren }}
$$

where: $S$ is the surface area of plantation, $M$ is the mass of crop on the unit of area of plantation, $\Omega$ is the general mass fraction of biofuel in the crop, and $V_{r e n}$ is the low caloric value of the biofuel.

Considering that every machine can work the definite width of the field in the single operation pass, the field has the shape of the parallelogram of the length $D$ and the width $W$, then its surface area is $S=D W$, and the slant side has the length:

$$
A=\frac{W}{\sin \alpha}
$$

In such a case, illustrated in Figure 1, when the moving machine works on the surface along the length of the field, during single pass elaborates the fragment of the surface equal to $s_{1}=D w$, the number of necessary strips needed to cover the whole area is $q_{1}$, which can be expressed as:

$$
q_{1}=\frac{W}{w}=\frac{D \times W}{D \times w}=\frac{S}{s_{1}}
$$




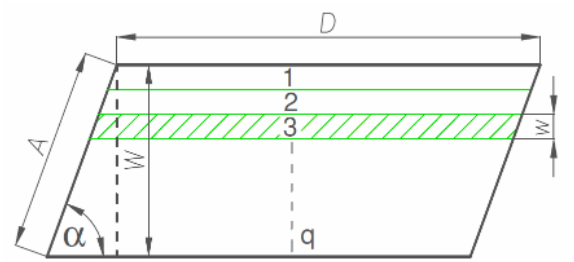

Figure 1. The field elaborated along the length, $D$.

Consequently, the length of the route, $R$, needed to cover the field is equal to:

$$
R=q \times A=\frac{D \sin \alpha}{w} \times \frac{W}{\sin \alpha}=\frac{D W}{w}
$$

It can be shown that a similar relationship giving the same result can be derived for the motion of machine along the side $A$.

The amount of energy consumed in tillage operations is therefore equal to

$$
P_{\text {in }}=\sum_{i}^{m} \frac{D \times W}{w_{i}} \times \delta_{i} \times V_{\text {cal }}
$$

After the extraction of constants outside of summation one obtains:

$$
P_{\text {in }}=V_{\text {cal }} \times S \times \sum_{i=1}^{m} \frac{\delta_{i}}{w_{i}}
$$

where $P_{\text {in }}$ is the energy consumed in tillage operations, $V_{\text {cal }}$ is the low caloric value of the fuel used for operations (might be fossil fuel or biofuel), $S$ is the surface area of plantation, $\delta_{i}$ is the fuel consumption per unit of the distance passed during the individual agro-technical process, $w_{i}$ is the width of the land strip operated in the single course of $i$-th operation, and $m$ is the number of the agro-technical operations (in each one of the operations, the width of the worked field, $w_{i}$, and the consumption of fuel, $\delta_{i}$, can be different).

The characteristics of equipment considered in the present case study are listed in Table 1.

Table 1. Fuel consumption needed in various tillage styles applied to the one hectare of the winter rape $\left[\mathrm{dm}^{3} / \mathrm{hm}^{2}\right]$.

\begin{tabular}{cccc}
\hline \multirow{2}{*}{ Tillage Type } & Tractor & \multicolumn{2}{c}{ Fuel Consumption } \\
\cline { 3 - 4 } & & $\begin{array}{c}\text { Without Forecrop } \\
{\left[\mathbf{d m}^{3} / \mathbf{h m}^{2}\right]}\end{array}$ & $\begin{array}{c}\text { With Forecrop (Lucerne) } \\
{\left[\mathbf{d m}^{3} / \mathbf{h m}^{2}\right]}\end{array}$ \\
\hline \multirow{2}{*}{ Classical } & Zetor 5340 $(65 \mathrm{KM})^{*}$ & 45 & 50 \\
Surface & Deutz Fahr TI4 Agrotron $(140 \mathrm{KM}) * *$ & 90 & 50 \\
\hline \multirow{2}{*}{ Direct sowing } & Zetor 5340 $(65 \mathrm{KM})^{*}$ & 37.5 & 100 \\
& Deutz Fahr TI4 Agrotron $(140 \mathrm{KM}) * *$ & 75 & 50 \\
\hline
\end{tabular}

* Specific fuel consumption $5 \mathrm{dm}^{3} / \mathrm{h} .{ }^{* *}$ specific fuel consumption $10 \mathrm{dm}^{3} / \mathrm{h}$. Source: author's computations based on empirical data collected from chosen agricultural farms.

\section{Results}

\subsection{Tillage Technology and Energetic Efficiency of Rapeseed Production Plantation}

During recent years, a number of papers [27-29] concerning various technologies of tillage have been published. Concerning rapeseed production, several main technologies can be distinguished: Classical, including plowing and seasoning of soil is used most frequently, however, the surface method 
consisting of the replacement of the plough by the furrow sowing has also become popular. Figures $2-4$ schematically show the operations occurring in several technologies of rapeseed cultivation.

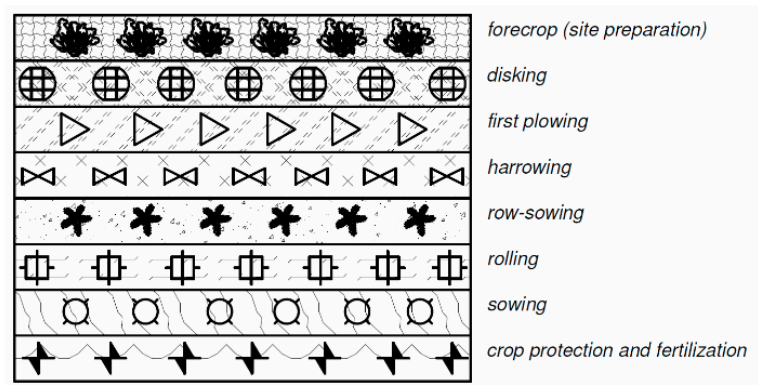

Figure 2. Agro-technical operations during classical cultivation of the winter rape.

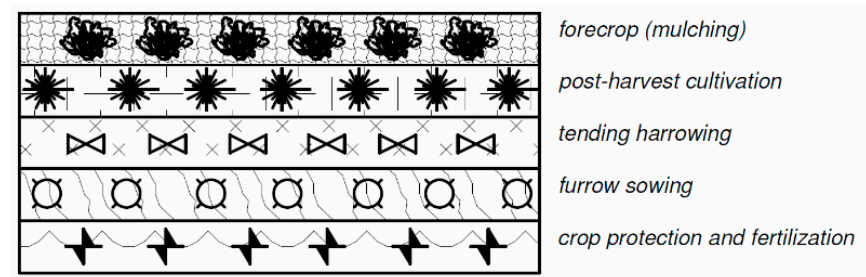

Figure 3. Agro-technical operations during surface cultivation of the winter rape.

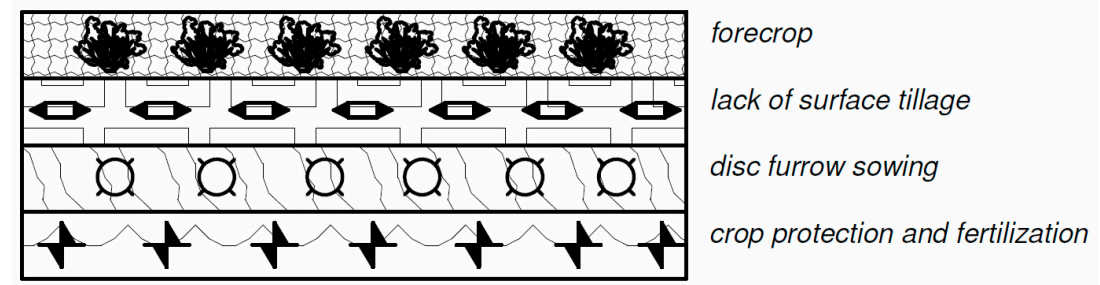

Figure 4. Agro-technical operations during direct sowing cultivation of the winter rape.

Rape cultivation is the energy-consuming process in which the choice of agro-technical operations determines the amount of energy consumed. This amount depends upon time and number of operations (including the eventual forecrop), the specific fuel consumption for a tractor, and the calorific value of the fuel applied. Table 2 gives the values of energy consumption for several choices of tractor, plantation sizes, types of tillage, and the use of forecrop. The values were computed for the calorific value of diesel fuel equal to $36\left[\mathrm{MJ} / \mathrm{dm}^{3}\right]$. (Variant I—without forecrop, variant II—with forecrop).

Table 2. Energy consumption in variants of the tillage operations on the rape plantations.

\begin{tabular}{|c|c|c|c|c|c|c|c|c|c|}
\hline $\begin{array}{c}\text { Area } \\
\text { [ha] }\end{array}$ & $\begin{array}{c}\text { Fuel } \\
\text { Variant } \\
\text { I [1/ha] }\end{array}$ & $\begin{array}{c}\text { Fuel } \\
\text { Variant } \\
\text { II }[1 / \mathrm{ha}]\end{array}$ & $\begin{array}{c}P_{i n} \\
\text { Variant } \\
\text { I [MJ] }\end{array}$ & $\begin{array}{c}\quad P_{i n} \\
\text { Variant } \\
\text { II [MJ] }\end{array}$ & $\begin{array}{c}\text { Area } \\
\text { [ha] }\end{array}$ & $\begin{array}{c}\text { Fuel } \\
\text { Variant } \\
\text { I [1/ha] }\end{array}$ & $\begin{array}{c}\text { Fuel } \\
\text { Variant } \\
\text { II }[1 / \text { ha }]\end{array}$ & $\begin{array}{c}P_{i n} \\
\text { Variant } \\
\text { I [MJ] }\end{array}$ & $\begin{array}{c}P_{\text {in }} \\
\text { Variant } \\
\text { II }[\mathrm{MJ}]\end{array}$ \\
\hline \multicolumn{5}{|c|}{ Classical Zetor (65 KM) } & \multicolumn{5}{|c|}{ Classical Deutz Fahr (140 KM) } \\
\hline 3 & 45 & 95 & 4860 & 10,260 & 3 & 90 & 190 & 9720 & 20,520 \\
\hline 12 & 45 & 95 & 19,440 & 41,040 & 12 & 90 & 190 & 38,880 & 82,080 \\
\hline 30 & 45 & 95 & 48,600 & 102,600 & 30 & 90 & 190 & 97,200 & 205,200 \\
\hline \multicolumn{5}{|c|}{ Surface Zetor (65 KM) } & \multicolumn{5}{|c|}{ Surface Deutz Fahr (140 KM) } \\
\hline 3 & 37.5 & 87.5 & 4050 & 9450 & 3 & 75 & 175 & 8100 & 18,900 \\
\hline 12 & 37.5 & 87.5 & 16,200 & 37,800 & 12 & 75 & 175 & 32,400 & 75,600 \\
\hline 30 & 37.5 & 87.5 & 40,500 & 94,500 & 30 & 75 & 175 & 81,000 & 189,000 \\
\hline
\end{tabular}


Table 2. Cont.

\begin{tabular}{cccccccccc}
\hline $\begin{array}{c}\text { Area } \\
{[\text { ha] }}\end{array}$ & $\begin{array}{c}\text { Fuel } \\
\text { Variant } \\
\text { I [1/ha] }\end{array}$ & $\begin{array}{c}\text { Fuel } \\
\text { Variant } \\
\text { II [1/ha] }\end{array}$ & $\begin{array}{c}\boldsymbol{P}_{\text {in }} \\
\text { Variant } \\
\text { I [M] }]\end{array}$ & $\begin{array}{c}\boldsymbol{P}_{\text {in }} \\
\text { Variant } \\
\text { II [M] }]\end{array}$ & $\begin{array}{c}\text { Area } \\
{[\text { ha] }}\end{array}$ & $\begin{array}{c}\text { Fuel } \\
\text { Variant } \\
\text { I [1/ha] }\end{array}$ & $\begin{array}{c}\text { Fuel } \\
\text { Variant } \\
\text { II [1/ha] }\end{array}$ & $\begin{array}{c}\boldsymbol{P}_{\text {in }} \\
\text { Variant } \\
\text { I [MJ] }\end{array}$ & $\begin{array}{c}\boldsymbol{P}_{\text {in }} \\
\text { Variant } \\
\text { II [MJ] }\end{array}$ \\
\hline \multicolumn{8}{c}{ Direct sowing Zetor $(65 \mathrm{KM})$} \\
\hline 3 & 30 & 80 & 3240 & 8640 & 3 & 60 & 160 & 6480 & 17,280 \\
12 & 30 & 80 & 12,960 & 34,560 & 12 & 60 & 160 & 25,920 & 69,120 \\
30 & 30 & 80 & 32,400 & 86,400 & 30 & 60 & 160 & 64,800 & 172,800 \\
\hline \multicolumn{7}{c}{ Source: own computations. }
\end{tabular}

The amount of energy produced from rapeseed grain is given in Table 3. The calorific value of biodiesel fuel was accepted as $V_{\text {cal }}=34.59\left[\mathrm{MJ} / \mathrm{dm}^{3}\right]$.

Table 3. Rapeseed biodiesel yield, and energy production from fields of various sizes.

\begin{tabular}{ccc}
\hline Field Area [ha] & Biodiesel Yield [1/ha] & Energy Yield [MJ] \\
\hline 3 & 1520 & $157,730.4$ \\
12 & 1520 & $630,921.6$ \\
30 & 1520 & $1,577,304$ \\
\hline \multicolumn{3}{c}{ Source: own computations. }
\end{tabular}

The data from Tables 2 and 3 enable computation of the net energy gain after energy consumption in agricultural operations was subtracted from the total energy yield. The values of net energy gain for various variants of production are, in turn, given in Table 4.

Table 4. Net energy gain from rapeseed plantation.

\begin{tabular}{|c|c|c|c|c|}
\hline \multicolumn{5}{|c|}{ Classical } \\
\hline \multirow{2}{*}{ Area [ha] } & $P_{n e t}$ I [MJ] & $P_{n e t}$ II [MJ] & $P_{n e t}$ I [MJ] & $P_{n e t}$ II [MJ] \\
\hline & Zetor & Zetor & Deutz & Deutz \\
\hline 3 & 152,870 & 147,470 & 148,010 & 137,210 \\
\hline 12 & 611,482 & 589,882 & 592,042 & 548,842 \\
\hline 30 & $1,528,704$ & $1,474,704$ & $1,480,104$ & $1,372,104$ \\
\hline \multicolumn{5}{|c|}{ Surface } \\
\hline 3 & 153,680 & 148,280 & 149,630 & 138,830 \\
\hline 12 & 614,722 & 593,122 & 598,522 & 555,322 \\
\hline 30 & $1,536,804$ & $1,482,804$ & $1,496,304$ & $1,388,304$ \\
\hline \multicolumn{5}{|c|}{ Direct Sowing } \\
\hline 3 & 154,490 & 149,090 & 151,250 & 140,450 \\
\hline 12 & 617,962 & 596,362 & 605,002 & 561,801 \\
\hline 30 & $1,544,904$ & $1,490,904$ & $1,512,504$ & $1,404,504$ \\
\hline
\end{tabular}

Based on data from Tables 2 and 3, it is also possible to evaluate partial energetic efficiency, after tillage operations are taken into account. The values, obtained according to Equation (1), are listed in Table 5. It is seen that values of partial energetic efficiency are independent of plantation size, but quite substantially depend upon the machine used, and upon the type of production technology. Obviously, the simpler cultivation technology is, the higher the energetic effectiveness of the plantation. Also, the use of a bigger tractor for relatively small plantations and introducing the forecrop evidently reduce the partial energetic effectiveness of the plantation. Consequently, the forecrop should be used when other energetic gains are expected. 
Table 5. Partial energetic efficiency of rapeseed plantations after energy inputs for tillage operations are considered.

\begin{tabular}{|c|c|c|c|c|}
\hline \multicolumn{5}{|c|}{ Classical } \\
\hline \multirow{2}{*}{ Area [ha] } & $P_{r e n} / P_{i n} \mathrm{I}[\mathrm{MJ}]$ & $P_{r e n} / P_{i n}$ II $[\mathrm{MJ}]$ & $P_{r e n} / P_{i n} \mathrm{I}[\mathrm{MJ}]$ & $\boldsymbol{P}_{r e n} / \boldsymbol{P}_{\text {in }}$ II $[\mathrm{MJ}]$ \\
\hline & Zetor & Zetor & Deutz & Deutz \\
\hline 3 & 32.45 & 15.37 & 16.23 & 7.69 \\
\hline 12 & 32.45 & 15.37 & 16.23 & 7.69 \\
\hline 30 & 32.45 & 15.37 & 16.23 & 7.69 \\
\hline \multicolumn{5}{|c|}{ Surface } \\
\hline 3 & 38.95 & 16.69 & 19.47 & 8.35 \\
\hline 12 & 38.95 & 16.69 & 19.47 & 8.35 \\
\hline 30 & 38.95 & 16.69 & 19.47 & 8.35 \\
\hline \multicolumn{5}{|c|}{ Direct Sowing } \\
\hline 3 & 48.68 & 18.26 & 24.34 & 9.13 \\
\hline 12 & 48.68 & 18.26 & 24.34 & 9.13 \\
\hline 30 & 48.68 & 18.26 & 24.34 & 9.13 \\
\hline
\end{tabular}

Source: own computations.

\subsection{The Effect of Internal Transport}

Besides tillage operations performed directly on the field, several transport operations are inseparably connected to agricultural production. Such operations include transport of machines to and from fields, transport of fertilizers and crop protection means, as well as transport of crops within the farm. The transport of grain or oil from the farm to an industrial facility needs to be treated separately. As was computed in Reference [30], the ratio of distance driven outside to the distance driven in the field, $R_{\text {out }} / R_{\text {agr }}$, varies between 0.1 and 0.35 for various, typical situations of a plantation with distributed fields. Those values have been used to estimate the energy consumed for internal transport in the present situation. Assuming that energy consumption on the field and outside the field are proportional to the corresponding distance driven with the same proportionality coefficient, one can conclude that the ratio $R_{\text {out }} / R_{a g r}$ is the same as the ratio $E_{\text {out }} / E_{\text {agr }}$. Therefore, to obtain the limiting values of energy spent on transportation, the values of net energy gain (given in Table 4 ) were multiplied by the ratio $R_{\text {out }} / R_{\text {agr }}$. The corresponding values of energy spent on transportation are given in Tables 6 and 7. Obviously the values given in Table 7, that correspond to the higher ratio $R_{\text {out }} / R_{\text {agr }}$, are much higher than those presented in Table 6.

Table 6. The energy consumed on transportation for the case $R_{\text {out }} / R_{a g r}=0.1$.

\begin{tabular}{|c|c|c|c|c|}
\hline \multicolumn{5}{|c|}{ Classical } \\
\hline \multirow{2}{*}{ Area [ha] } & $P_{c a r}$ I [MJ] & $P_{c a r}$ II [MJ] & $P_{c a r}$ I [MJ] & $P_{c a r}$ II [MJ] \\
\hline & Zetor & Zetor & Deutz & Deutz \\
\hline 3 & 15,287 & 14,747 & 14,801 & 13,721 \\
\hline 12 & $61,148.2$ & $58,988.2$ & $59,204.2$ & $54,884.2$ \\
\hline 30 & $152,870.4$ & $147,470.4$ & $148,010.4$ & $137,210.4$ \\
\hline \multicolumn{5}{|c|}{ Surface } \\
\hline 3 & 15,368 & 14,828 & 14,963 & 13,883 \\
\hline 12 & $61,472.2$ & $59,312.2$ & $59,852.2$ & $55,532.2$ \\
\hline 30 & $153,680.4$ & $148,280.4$ & $149,630.4$ & $138,830.4$ \\
\hline \multicolumn{5}{|c|}{ Direct Sowing } \\
\hline 3 & 15,449 & 14,909 & 15,125 & 14,045 \\
\hline 12 & $61,796.2$ & $59,636.2$ & $60,500.2$ & $56,180.1$ \\
\hline 30 & $154,490.4$ & $149,090.4$ & $151,250.4$ & $140,450.4$ \\
\hline
\end{tabular}

Source: own computations. 
Table 7. The energy consumed on transportation for the case $R_{\text {out }} / R_{\text {agr }}=0.35$.

\begin{tabular}{|c|c|c|c|c|}
\hline \multicolumn{5}{|c|}{ Classical } \\
\hline \multirow{2}{*}{ Area [ha] } & $P_{c a r}$ I [MJ] & $P_{c a r}$ II [MJ] & $P_{c a r} \mathbf{I}[\mathrm{MJ}]$ & $P_{c a r}$ II $[\mathrm{MJ}]$ \\
\hline & Zetor & Zetor & Deutz & Deutz \\
\hline 3 & $53,504.5$ & $51,614.5$ & $51,803.5$ & $48,023.5$ \\
\hline 12 & $214,018.7$ & $206,458.7$ & $207,214.7$ & $192,094.7$ \\
\hline 30 & $535,046.4$ & $516,146.4$ & $518,036.4$ & $480,236.4$ \\
\hline \multicolumn{5}{|c|}{ Surface } \\
\hline 3 & 53,788 & 51,898 & $52,370.5$ & $48,590.5$ \\
\hline 12 & $215,152.7$ & $207,592.7$ & $209,482.7$ & $194,362.7$ \\
\hline 30 & $537,881.4$ & $518,981.4$ & $523,706.4$ & $485,906.4$ \\
\hline \multicolumn{5}{|c|}{ Direct Sowing } \\
\hline 3 & $54,071.5$ & $52,181.5$ & $52,937.5$ & $49,157.5$ \\
\hline 12 & $216,286.7$ & $208,726.7$ & $211,750.7$ & $196,630.4$ \\
\hline 30 & $540,716.4$ & $521,816.4$ & $529,376.4$ & $491,576.4$ \\
\hline
\end{tabular}

Source: own computations.

The values of energy consumed on transportation can be finally used to compute partial energetic efficiency of transportation for two limiting values of internal transport contribution to the energy consumed by the production system. These are reported in Tables 8 and 9 .

Table 8. Partial energetic efficiency of internal transport when $R_{\text {out }} / R_{\text {agr }}=0.1$.

\begin{tabular}{|c|c|c|c|c|}
\hline \multicolumn{5}{|c|}{ Classical } \\
\hline \multirow{2}{*}{ Area [ha] } & $\boldsymbol{P}_{r e n} \mathrm{I} / \boldsymbol{P}_{c a r}$ & $P_{r e n} \mathrm{II} / P_{c a r}$ & $\boldsymbol{P}_{r e n} \mathrm{I} / \boldsymbol{P}_{c a r}$ & $\boldsymbol{P}_{\text {ren }} \mathrm{II} / \boldsymbol{P}_{\text {car }}$ \\
\hline & Zetor & Zetor & Deutz & Deutz \\
\hline 3 & 10.4 & 10.7 & 10.7 & 11.5 \\
\hline 12 & 10.4 & 10.7 & 10.7 & 11.5 \\
\hline 30 & 10.4 & 10.7 & 10.7 & 11.5 \\
\hline \multicolumn{5}{|c|}{ Surface } \\
\hline 3 & 10.3 & 10.7 & 10.6 & 11.4 \\
\hline 12 & 10.3 & 10.7 & 10.6 & 11.4 \\
\hline 30 & 10.3 & 10.7 & 10.6 & 11.4 \\
\hline \multicolumn{5}{|c|}{ Direct Sowing } \\
\hline 3 & 10.3 & 10.6 & 10.5 & 11.3 \\
\hline 12 & 10.3 & 10.6 & 10.5 & 11.3 \\
\hline 30 & 10.3 & 10.6 & 10.5 & 11.3 \\
\hline
\end{tabular}

Source: own computations.

It is seen from Tables 8 and 9 that values of partial energetic effectiveness for internal transport are quite low. They are independent of plantation size and are only slightly affected by the types of tractors and methods of tillage. Application of Equation (2) to the data contained in Tables 5, 8 and 9, give the final energetic efficiency, $\varepsilon$, for both cases of partial energetic efficiency of transport. The resulting values are summarized in Tables 10 and 11 . The resulting values are evidently decreased with respect to the data in Table 5. The decrease is more pronounced when the partial energetic efficiency of transport is smaller. 
Table 9. Partial energetic efficiency of internal transport when $R_{\text {out }} / R_{\text {agr }}=0.35$.

\begin{tabular}{|c|c|c|c|c|}
\hline \multicolumn{5}{|c|}{ Classical } \\
\hline \multirow{2}{*}{ Area [ha] } & $P_{r e n} \mathrm{I} / P_{c a r}$ & $P_{r e n} \mathrm{II} / P_{c a r}$ & $\boldsymbol{P}_{\text {ren }} \mathrm{I} / \boldsymbol{P}_{\text {car }}$ & $P_{r e n} \mathrm{II} / P_{c a r}$ \\
\hline & Zetor & Zetor & Deutz & Deutz \\
\hline 3 & 2.95 & 3.06 & 3.05 & 3.29 \\
\hline 12 & 2.95 & 3.06 & 3.05 & 3.29 \\
\hline 30 & 2.95 & 3.06 & 3.05 & 3.29 \\
\hline \multicolumn{5}{|c|}{ Surface } \\
\hline 3 & 2.94 & 3.04 & 3.02 & 3.25 \\
\hline 12 & 2.94 & 3.04 & 3.02 & 3.25 \\
\hline 30 & 2.94 & 3.04 & 3.02 & 3.25 \\
\hline \multicolumn{5}{|c|}{ Direct Sowing } \\
\hline 3 & 2.92 & 3.03 & 2.98 & 3.21 \\
\hline 12 & 2.92 & 3.03 & 2.98 & 3.21 \\
\hline 30 & 2.92 & 3.03 & 2.98 & 3.21 \\
\hline
\end{tabular}

Source: own computations.

Table 10. Resulting energetic efficiency of internal transport when $R_{\text {out }} / R_{\text {agr }}=0.1$.

\begin{tabular}{|c|c|c|c|c|}
\hline \multicolumn{5}{|c|}{ Classical } \\
\hline \multirow{2}{*}{ Area [ha] } & $\boldsymbol{P}_{\text {ren }} \mathrm{I} / \boldsymbol{P}_{\text {car }}$ & $\boldsymbol{P}_{\text {ren }} \mathrm{II} / \boldsymbol{P}_{c a r}$ & $\boldsymbol{P}_{\text {ren }} \mathrm{I} / \boldsymbol{P}_{\text {car }}$ & $P_{\text {ren }} \mathrm{II} / P_{c a r}$ \\
\hline & Zetor & Zetor & Deutz & Deutz \\
\hline 3 & 7.9 & 6.4 & 6.5 & 4.7 \\
\hline 12 & 7.9 & 6.4 & 6.5 & 4.7 \\
\hline 30 & 7.9 & 6.4 & 6.5 & 4.7 \\
\hline \multicolumn{5}{|c|}{ Surface } \\
\hline 3 & 8.2 & 6.6 & 6.9 & 4.9 \\
\hline 12 & 8.2 & 6.6 & 6.9 & 4.9 \\
\hline 30 & 8.2 & 6.6 & 6.9 & 4.9 \\
\hline \multicolumn{5}{|c|}{ Direct Sowing } \\
\hline 3 & 8.6 & 6.8 & 7.4 & 5.1 \\
\hline 12 & 8.6 & 6.8 & 7.4 & 5.1 \\
\hline 30 & 8.6 & 6.8 & 7.4 & 5.1 \\
\hline
\end{tabular}

Table 11. Resulting energetic efficiency of internal transport when $R_{\text {out }} / R_{\text {agr }}=0.35$.

\begin{tabular}{|c|c|c|c|c|}
\hline \multicolumn{5}{|c|}{ Classical } \\
\hline \multirow{2}{*}{ Area [ha] } & $\boldsymbol{P}_{\text {ren }} \mathrm{I} / \boldsymbol{P}_{\text {car }}$ & $P_{\text {ren }} \mathrm{II} / P_{c a r}$ & $P_{\text {ren }} \mathrm{I} / P_{c a r}$ & $P_{\text {ren }} \mathrm{II} / P_{\text {car }}$ \\
\hline & Zetor & Zetor & Deutz & Deutz \\
\hline 3 & 2.8 & 2.6 & 2.6 & 2.4 \\
\hline 12 & 2.8 & 2.6 & 2.6 & 2.4 \\
\hline 30 & 2.8 & 2.6 & 2.6 & 2.4 \\
\hline \multicolumn{5}{|c|}{ Surface } \\
\hline 3 & 2.8 & 2.6 & 2.7 & 2.4 \\
\hline 12 & 2.8 & 2.6 & 2.7 & 2.4 \\
\hline 30 & 2.8 & 2.6 & 2.7 & 2.4 \\
\hline \multicolumn{5}{|c|}{ Direct Sowing } \\
\hline 3 & 2.8 & 2.6 & 2.7 & 2.4 \\
\hline 12 & 2.8 & 2.6 & 2.7 & 2.4 \\
\hline 30 & 2.8 & 2.6 & 2.7 & 2.4 \\
\hline
\end{tabular}




\section{Discussion}

According to Equation (2), combinations of partial energetic efficiencies cause a decrease of the global one. Consequently, internal transport outside the fields may drastically decrease the total efficiency of the system. It can be concluded, therefore, that when planning the production system, one has to take into account the possibly small distances between the fields, and possibly efficient machinery for both tillage operations as well as local transport outside of the fields. Since the agricultural subsystem is only a segment in the total chain of operations that have to be performed, not only to produce rapeseed grain but also to convert it to biofuel, which again requires transport and inputs of energy into industrial operations, one might expect a further decrease of energetic efficiency. The present study indicates that the contribution of transport may be in some cases bigger than that of tillage operations. Assuming that energetic self-sufficiency is one of the conditions of sustainability of agriculture it would be reasonable to reduce the energy consumption of transport operations. Such a reduction may be achieved by several technological and organizational procedures, e.g., reducing distances between facilities, reducing the amounts of transported goods by preliminary treatment, etc.

Present analysis indicates that the internal transport of machinery and goods in the agricultural part of the biofuels production systems contributes in a small degree to the energetic efficiency of that system. This result is based upon specific assumptions made with respect to the structure of the plantation. Obviously an increase of distances between fields would cause the increase of transport contribution to a decrease of energetic effectiveness. Similar effects would be observed when small fields are separated by long distances. External transport might play an important role, i.e., the transport between the plantation and the industrial facilities. This problem is not analyzed in the present paper, but its existence is worth being mentioned.

\section{Conclusions}

Besides agricultural operations, the internal transport of machinery and goods appears to be an important factor for reducing the energetic effectiveness of biofuel production systems. The low values of energetic effectiveness mean that a large part of the arable land should be converted into biofuel production plantations to achieve energetic self-sufficiency of agriculture. Such an increase of the fraction of arable land dedicated to biofuel production would arise the danger for food production. It is, therefore, necessary to look for ways of increasing the energetic effectiveness of all processes contributing to biofuel production. Appropriate choice of production technology and transportation means, proper organization of internal logistic processes, etc. may substantially contribute to improved sustainability of agriculture, and also sustainability of the whole economy.

The present bioenergy trends have also considered using a biomass form other than agricultural land plantations. Examples of such an approach are presented in References [31,32], which indicate the biomass production potential located in urban areas, as well as on roadside shoulders. Similar possibility is shown in Reference [33] which discusses the municipal wastes as a possible resource for fuels production. References [34,35] discuss the logistic aspect of sustainability, which also corresponds to the topic of the present paper, underlining the important role of energy used for transport in determining the energetic efficiency of various processes.

Author Contributions: Conceptualization, O.O. and A.Ś.; Methodology, O.O.; Validation, A.Ś.; Investigation, O.O.; Writing-Original Draft Preparation, O.O.; Funding Acquisition, O.O. and A.Ś.

Funding: (1) Investigations were realized within statutory research project No. S/WZ/1/2015, and funded from financial resources for science provided by Ministry of Science and Higher Education (O.O.). (2) Statutory research project of Lublin University of Technology, No. S54/M/2018 (A.Ś.)

Acknowledgments: One of the authors (O.O.) is indebted to A. L. Wasiak for valuable discussions. 
Conflicts of Interest: The authors declare no conflict of interest. The funders had no role in the design of the study; in the collection, analyses, or interpretation of data; in the writing of the manuscript, and in the decision to publish the results.

\section{References}

1. Morelli, J. Environmental sustainability: And definition for environmental professionals. J. Environ. Sustain. 2011, 1, 1-9. [CrossRef]

2. McLellan, B.; Zhang, Q.; Farzaneh, H.; Agya Utama, N.; Ishihara, K.N. Resilience, sustainability and risk management: And focus on energy. Challenges 2012, 3, 153-182. [CrossRef]

3. McLellan, B.C.; Corder, G.D.; Golev, A.; Ali, S.H. Sustainability of the rare earths industry. Procedia Environ. Sci. 2014, 20, 280-287. [CrossRef]

4. Ciegis, R.; Ramanauskiene, J.; Martinkus, B. The concept of sustainable development and its use for sustainability scenarios. Econ. Cond. Enterp. Funct. 2009, 2, 28-37.

5. Pretty, J. Agricultural sustainability: Concepts, principles and evidence. Philos. Trans. R. Soc. B 2008, 363, 447-465. [CrossRef] [PubMed]

6. Kissinger, M.; Rees, W.E.; Timmer, V. Interregional sustainability: Governance and policy in an ecologically interdependent world. Environ. Sci. Policy 2011, 14, 965-976. [CrossRef]

7. Afgan, N.H.; Gobaisi, D.A.; Carvalho, M.G.; Mooring, M. Sustainable energy development. Renew. Sustain. Energy Rev. 1998, 2, 235-286. [CrossRef]

8. Lior, N. Sustainable energy development (May 2011) with some game-changers. Energy 2012, 40, 3-18. [CrossRef]

9. Goldemberg, J. Ethanol for and Sustainable Energy Future. Sustain. Energy 2007, 315, 808-810. [CrossRef] [PubMed]

10. Wasiak, A. The effect of biofuel production on sustainability of agriculture. Biol. Syst. Open Access 2016, 5, 1-7. [CrossRef]

11. Zhang, Y.; Colosi, L.M. Practical ambiguities during calculation of energy ratios and their impacts the lifecycle assessment calculations. Energy Policy 2013, 57, 630-633. [CrossRef]

12. Murphy, D.J.; Hall, C.A.S.; Dale, M.; Cleveland, C. Order from chaos: A preliminary protocol for determining the EROEI of fuels. Sustainability 2011, 3, 1888-1907. [CrossRef]

13. Fontaras, G.; Skoulou, V.; Zanakis, G.; Zabaniotou, A.; Samaras, Z. Integrated environmental assessment of energy crops for biofuel and energy production in Greece. Renew. Energy 2012, 43, 201-209. [CrossRef]

14. Russo, D.; Dassisti, M.; Lawlor, A.; Olabi, A.G. State of the art of biofuels from pure plant oil. Renew. Sustain. Energy Rev. 2012, 16, 4056-4070. [CrossRef]

15. Talens, L.; Villalba, G.; Gabarrell, X. Exergy analysis applied to biodiesel production. Resour. Conserv. Recycl. 2007, 51, 397-407. [CrossRef]

16. Liao, W.; Heijungs, R.; Huppes, G. Is bioethanol a sustainable energy source? An energy-, exergy-, and emergy-based thermodynamic system analysis. Renew. Energy 2011, 36, 3479-3487. [CrossRef]

17. Nasir, N.F.; Daud, W.R.W.; Kamarudin, S.K.; Yaakob, Z. Process system engineering in biodiesel production: A review. Renew. Sustain. Energy Rev. 2013, 22, 631-639. [CrossRef]

18. Okoro, O.V.; Sun, Z.; Birch, J. Catalyst-free biodiesel production methods: A comparative technical and environmental evaluation. Sustainability 2018, 10, 127. [CrossRef]

19. Giraldi-Díaz, M.R.; De Medina-Salas, L.; Castillo-González, E.; De la Cruz-Benavides, M. Environmental impact associated wih the supply chain and production of biodiesel from Jatropha curcas L. through life cycle analysis. Sustainability 2018, 10, 1451. [CrossRef]

20. Bacenetti, J.; Restuccia, A.; Schillaci, G.; Failla, S. Biodiesel production from unconventional oilseed crops (Linum usitatissimum L. and Camelina sativa L.) in Mediterranean conditions: Environmental sustainability assessment. Renew. Energy 2017, 112, 444-456. [CrossRef]

21. Biruk, S.; Jaśkowski, P.; Czarnigowska, A. Modelling contractor's bidding decision. Eng. Manag. Prod. Serv. 2017, 9, 64-79. [CrossRef]

22. Czech, A.; Biezdudnaja, A.; Lewczuk, J.; Razumowskij, W. Quantitative assessment of urban transport development-A spatial approach. Eng. Manag. Prod. Serv. 2018, 10, 32-44. [CrossRef] 
23. Nazarko, J.; Ejdys, J.; Halicka, K.; Nazarko, Ł.; Kononiuk, A.; Olszewska, A. Structural analysis as an instrument for identification of critical divers of technology development. Procedia Eng. 2017, 182, 474-481. [CrossRef]

24. Ejdys, J.; Matuszak-Fejszaman, A. New management systems as an instrument of implementation sustainable development concept at organizational level. Technol. Econ. Dev. Econ. 2010, 16, 202-218. [CrossRef]

25. Wasiak, A.; Orynycz, O. Formulation of a model for energetic efficiency of agricultural subsystem of biofuel production. In Proceedings of the 2014 IEEE International Energy Conference (ENERGYCON), Cavtat, Croatia, 13-16 May 2014; pp. 1333-1337.

26. Wasiak, A.; Orynycz, O. The effects of energy contributions into subsidiary processes on energetic efficiency of biomass plantation supplying biofuel production system. Agric. Agric. Sci. Procedia 2015, 7, 292-300. [CrossRef]

27. Barnwal, B.K.; Scharma, M.P. Prospects of biodiesel production from vegetable oils in India. Renew. Sustain. Energy Rev. 2005, 9, 363-378. [CrossRef]

28. Abnisa, F.; Wan Daud, W.M.A.; Husin, W.N.W.; Sahu, J.N. Utilization possibilities of palm shell as a source of biomass energy in Malaysia by producing bio-oil in pyrolysis process. Biomass Bioenergy 2011, 35, 1863-1872. [CrossRef]

29. Painuly, J.P.; Rao, H.; Parikh, J. A rural energy-agriculture interaction model applied to Karnataka state. Energy 1995, 20, 219-233. [CrossRef]

30. Wasiak, A.; Orynycz, O. Energy efficiency of biofuel production system. Manag. Prod. Eng. Rev. 2017, 8, 60-68. [CrossRef]

31. Arodudu, O.T.; Ibrahim, E.S.; Voinov, A.; van Duren, I. Exploring bioenergy potentials of built-up areas based on NEG-EROEI indicators. Ecol. Indic. 2014, 47, 67-69. [CrossRef]

32. Voinov, A.; Arodudu, O.; van Duren, I.; Morales, J.; Qin, L. Estimating the potential of roadside vegetation for bioenergy production. J. Clean. Prod. 2015, 102, 213-225. [CrossRef]

33. Di Matteo, U.; Nastasi, B.; Albo, A.; Garcia, D.A. Energy contribution of MSW (organic fraction of municipal solid waste) to energy-environmental sustainability in urban areas at small scale. Energies 2017, 10, 229. [CrossRef]

34. Kalenoja, H.; Kallionpää, E.; Rantala, J. Indicators of energy efficiency of supply chains. Int. J. Logist. Res. Appl. 2011, 14, 77-95. [CrossRef]

35. Marci, B.; Zanoni, S. Supply chain management for improved energy efficiency: Review and opportunities. Energies 2017, 10, 1618. [CrossRef] 